\title{
Perbedaan Intensitas Komunikasi Melalui Jejaring Sosial antara Tipe Kepribadian Ekstrovert dan Introvert pada Remaja
}

\author{
Komang Sri Widiantari dan Yohanes Kartika Herdiyanto \\ Program Studi Psikologi, Fakultas Kedokteran, Universitas Udayana \\ omangomeng@yahoo.com
}

\begin{abstract}
Abstrak
Kemajuan teknologi komunikasi informasi salah satunya ditandai dengan meningkatnya penggunaan media jejaring sosial. Pengguna jejaring sosial sebagian besar adalah kelompok remaja, keberadaan media jejaring sosial dapat menimbulkan dampak positif dan jugadampaknegatif padamasyarakat khususnya remaja. Penelitian ini bertujuan untuk mengetahui perbedaan intensitas komunikasi melalui jejaring sosial antara tipe kepribadian ekstrovert dan introvert pada remaja.

Penelitian ini merupakan penelitian kuantitatif dengan metoda komparasi, teknik sampling yang digunakan yaitu stratified proporsional randomsampling. Populasi dalam penelitian ini adalah siswa SMA Negeri di Denpasar,denganresponden sebanyak218 orang. Dari analisis data menggunakan independent sampel t-test, hasil menunjukkan bahwa terdapat perbedaan intensitas komunikasi melalui jejaring sosial antara tipe kepribadian introvert danekstrovert pada remaja, yaitu tipe kepribadian ekstrovert mempunyai intensitas komunikasi yang tinggi dibandingkan dengan tipe kepribadian introvert. Selain itu, dapat dinyatakan bahwa terdapat hubungan antara jumlah jejaring sosial dengan intensitas komunikasi melalui jejaring sosial, serta tidak terdapat perbedaan intensitas komunikasi melalui jejaring sosial antara laki-laki dan perempuan.
\end{abstract}

Kata kunci: Intensitas komunikasi, jejaring sosial, ekstrovert, introvert

\begin{abstract}
The progress of information and communication technology influencethe increase of the usage of social network. Social network users are mostly inadult group. The existence of social networks can bring positive impact as well as negative impact to the society especially in adult group. The aim of this research is to find out the difference in communication intensity through social networks between extrovert and introvert types of personality in adolescents.

This research is a quantitative research with comparative method, the sampling technique used in this research is stratified proporsional randomsampling and the population is High School students in Denpasar, with the total respondents 218 student. The analysis data by t-test independent sample, and shown the result that there was a difference in the communication intensity through social network between introvert and extrovert type of personality in adolescents, the extrovert personality had a high level of communication better than introvert personality. The additional analysis, it is stated that there was a relationship between the number of social networks and the intensity of communication on social networks, and there was no difference in the intensity of communication based on gender.
\end{abstract}

Keywords: Communication intensity, social networks, extrovert,introvert 


\section{LATAR BELAKANG}

Perkembangan era globalisasi salah satunya ditandai dengan kemajuan teknologi khususnya dalam bidang komunikasi informasi. Komunikasi dilakukan dalam memenuhi kebutuhan manusia untuk melakukan interaksi dengan orang lain terkait fungsi manusia sebagai makhluk sosial. Menurut Devito (dalam Sulaeman, 2010) sifat komunikasi terbagi dalam 2 jenis yaitu komunikasi secara langsung dan tidak langsung, komunikasi langsung merupakan komunikasi yang dilakukan dengan saling bertatap muka dalam suatu aktivitas komunikasi tanpa menggunakan perantara media, sedangkan komunikasi secara tidak langsung merupakan komunikasi yang dilakukan dengan tidak bertemu secara langsung dalam suatu aktivitas komunikasi, komunikasi dilakukan dengan menggunakan perantara mediaseperti email, handphone, jejaring sosial, dan yahoo messenger.

Kemajuan teknologi komunikasi dapat membantu manusia untuk berinteraksi satu sama lain tanpa dibatasi oleh jarak dan waktu. Salah satu contoh perkembangan teknologi komunikasi yang ada di masyarakat adalah munculnya berbagai media jejaring sosial seperti twitter, facebook, myspace dan friendster. Keistimewaan dari jejaring sosial adalah kemampuan dalam keluasan jaringan dan kecepatan informasi yang dapat memfasilitasi tuntutan dan kebutuhan komunikasi dari berbagai kalangan masyarakat yang memberikan kemudahan dalam mengakses informasi. Hal ini menunjukkan bahwa komunikasi melalui jejaring sosial sebagai kebutuhan dan gaya hidup yang didukung dengan tersedianya berbagai jenis handphone dan perangkat elektronik yang menyediakan berbagai fitur khusus sehingga dapat langsung tersambung di jejaring sosial.

Data Kementerian Komunikasi dan Informasi RI tahun 2011 menunjukkan terdapat 64\% pengguna jejaring sosial di Indonesia adalah kelompok remaja (Hariyanti, 2011), Tingginya penggunaan jejaring sosial dikalangan remaja menunjukkan bahwa remaja begitu antusias dalam menggunakan media jejaring sosial untuk melakukan komunikasi. Kebutuhan untuk memiliki hubungan dengan orang lain pada umumnya tinggi ketika manusia berada pada tahap perkembangan remaja (Papalia, Olds, \& Feldman, 2007). Masa remaja merupakan periode transisi perkembangan antara masa kanak-kanak dengan masa dewasa, melibatkan perubahan biologis, kognitif dan sosial.Perubahan biologis ditandai dengan pertumbuhan tinggi badan, perubahan hormonal dan kematangan organ seksual yang ditandai dengan pubertas,kematangan secara kognitif melibatkan perubahan pemikiran dan intelegensi individu.Secara sosial ditandai dengan adanya tuntutan untuk mencapai kemandirian dan perubahan dalam menjalin relasi dengan orang lain dalam konteks sosial (Santrock, 2007).

Khususnya pada masa remaja pertengahan, seseorang lebih banyak membutuhkan interaksi dengan orang lain untuk memperoleh pembanding dirinya baik mengenai sikap, pendapat, pikiran atau yang lainnya yang berkaitan dengan pembentukan jati diri (Yoseptian, Soewondo, \& Zulkaida, 2011).Berdasarkan data dari World Economic Forum tingginya penggunaan internet di Indonesia karena adanya berbagai jejaring sosial yang mudah diakses dan sesuai untuk kebutuhan penggunanya seperti facebook, dan twitter(Sunggiardi, 2012). Jumlah pengguna facebook di Indonesia saat ini sebesar 40,4 juta orang dan menduduki peringkat kedua pengguna facebook terbesar di dunia, sedangkan penggunaan twitter berada di peringkat keempat sebanyak 22\% dari pengguna twitter di dunia (Arfika, 2012).

Perkembangan dalam dunia komunikasi menciptakan pengaruh yang sangat besar bagi perkembangan sosial dan peradaban manusia.Keberadaan media jejaring sosial dapat menimbulkan dampak positif dan juga dampak negatif pada masyarakat khususnya remaja.Dampak positif media jejaring sosial adalah memperluas jaringan pertemanan, sebagai media penyebaran informasi dan sarana untuk mengembangkan keterampilan, sedangkan dampak negatif yang ditimbulkan akibat penggunaan jejaring sosial secara berlebihan antara lain kecanduan internet, pencurian identitas, dan meningkatnya sifat antisosial (Raihana, 2009). Semakin banyak masyarakat yang menggunakan jejaring sosial, maka semakin banyak hal positif maupun negatif yang dapat ditimbulkan baik untuk pengguna maupun lingkungan sekitarnya.Jejaring sosial merupakan layanan internet yang ditujukan sebagai komunitas online bagi pengguna yang memiliki kesamaan aktivitas, ketertarikan, atau kesamaan latar balakang pada bidang tertentu.Jejaring sosial juga didefinisikan sebagai jaringan pertemanan yang dilengkapi dengan beragam fitur bagi penggunanya sehingga dapat saling berkomunikasi dan berinteraksi (Imran, 2009).

Penggunaan jejaring sosial berkaitan dengan intensitas komunikasi yang dilakukan oleh pengguna jejaring sosial dalam melakukan interaksi dengan orang lain secara online, intensitas komunikasi merupakan keadaan, tingkatan atau ukuran lamaya kejadian komunikasi (Devito, 1997). Intensitas komunikasi ditandai dengan adanya frekuensi berkomunikasi yang terkait dengan tingkat keseringan seseorang dalam melakukan aktivitas komunikasi, durasi yang digunakan untuk berkomunikasi terkait dengan lamanya waktu yang digunakan pada saat melakukan aktivitas komunikasi, perhatian yang diberikan saat berkomunikasi diartikan sebagai fokus yang dicurahkan oleh partisipan komunikasi pada saat berkomunikasi, keteraturan dalam berkomunikasi menunjukan kesamaan sejumlah aktivitas komunikasi yang dilakukan secara rutin dan teratur, tingkat keluasan pesan saat berkomunikasi dan jumlah orang yang diajak berkomunikasi mempunyai arti ragam topik maupun pesan yang dibicarakan pada saat berkomunikasi dan jumlah orang yang diajak berkomunikasi berkaitan dengan kuantitas 
atau banyaknya orang yang diajak untuk berkomunikasi pada saat melakukan aktivitas komunikasi sedangkan tingkat kedalaman pesan merujuk pada pertukaran pesan secara lebih detail yang ditandai dengan kejujuran, keterbukaan, dan sikap saling percaya antar partisipan pada saat berkomunikasi (Devito, 1997).

Media jejaring sosial dapat digunakan oleh siapa saja, kapan saja dan dimana saja, sehinggahal tersebut menjadi salah satu mediator untuk dapat saling berkomunikasi dan menjadikan jejaring sosial sebagai media komunikasi yang efektif dan efisien. Proses komunikasi menggunakan perangkat komputer berjaringan internet disebut denganComputer Mediated Communications (CMC)(Ramdhani, 2006). Computer Mediated Communications merupakan komunikasi antar dua orang atau lebih yang dapat saling berinteraksi melalui komputer yang berbeda dengan menggunakan alatbantu komputer melalui program aplikasi yang ada pada komputer tersebut yang disampaikandalam bentuk tulisan, gambar, suara, dan video (Yoseptian, Soewondo, \& Zulkaida, 2011). Salah satu contoh CMC yang saat ini sedang populer dikalangan remaja adalah komunikasi menggunakan situs jejaring sosial seperti line, path instagram, facebook dan twitter. Jejaring sosial disebut sebagai jaringan pertemanan, berbasis web, dilengkapi dengan beragam fitur bagi penggunanya sehingga dapat saling melakukan komunikasi dan menjalin interaksi (Imran, 2009).

Sebuah teknologi pada hakikatnya diciptakan untuk membuat hidup manusia menjadi semakin udah dan nyaman, tuntutan kebutuhan pertukaran informasi yang cepat, peranan teknologi komunikasi menjadi sangat penting, teknologi sangat bermanfaat dalam memudahkan manusia untuk mencapai sesuatu yang diinginkan secara efisisen dalam waktu yang singkat. Salah satu cara yang digunakan remaja dalam memenuhi kebutuhan untuk menjalin komunikasi yaitu dengan menggunakan media jejaring sosial.Munculnya media jejaring sosial berbanding terbalik dengan frekuensi komunikasi tatap muka antar pribadi yang dilakukan baik pada individu dengan tipe kepribadian ekstrovert dan introvert.Intensitas komunikasi menggunakan jejaring sosial yang berlebihan dapat menjadi candu karena kesenangan yang ditawarkan, seseorang dengan intensitas komunikasi tinggi dalam menggunakan jejaring sosial maka semakin rendah intensitas komunikasi tatap muka pada komunikasi antarpribadi (Sulaeman, 2010).Komunikasi berfungsi untuk menghubungkan dan mengajak orang lain untuk mengerti apa yang kita sampaikan, apabila penerima berita mengerti benar mengenai pesan yang disampaikan pengirim pesan, maka dapat disebut sebagai komunikasi yang efektif, jika tidak, maka terjadi kesalahan pesan atau disebut miscomunication. Terdapat lima unsur dalam proses komunikasi yang terdiri dari adanya pengirim berita, penerima berita, adanya berita yang dikirimkan, adanya media atau alat pengirim berita serta adanya sistem yang digunakan untuk menyatakan berita (Sarwono, 2012). Komunikasi menggunakan media jejaring sosial dijadikan sarana pengganti proses komunikasi secara tatap muka. Penggunaan komunikasi media jejaring sosial dapat menimbulkan ketidak sepahaman terhadap makna dan tujuan pesan yang disampaikan dalam berkomunikasi, hal ini dikarenakan komunikasi melalui jejaring sosial tanpa disertai dengan bahasa nonverbal, padahal komunikasi nonverbal dapat membantu menekankan beberapa bagian dari pesan verbal (Devito, 1997).

Dalam pemanfaatan penggunaan media jejaring sosial, pengguna cenderung memiliki karakteristik yang berbeda. Hal ini dikarenakan setiap orang memiliki pengalaman, motif, sikap dan tipe kepribadian yang relatif berbeda dalam penggunaan jejaring sosial.Kepribadian bersifat unik dan konsisten sehingga dapat digunakan untuk mebedakan antara individu satu dengan lainnya. Terkait dengan perbedaan tipe kepribadian, Jung menggolongkan kepribadian menjadi dua yaitu tipe kepribadian ekstrovert dan introvert(Suryabrata, 2002).Kepribadian dalam bahasa inggris disebut dengan istilah personality, istilah ini berasal dari bahasa latin yaitu persona yang berarti topeng, topeng digunakan dalam pertunjukan drama untuk mewakili karakteristik kepribadian tertentu, berdasarkan penjelasan tersebut kepribadian diartikan sebagai seseorang yang nampak di hadapan orang lain (Irwanto, 1989).

Kepribadian merupakan karakteristik seseorang yang menyebabkan munculnya konsistensi perasaan, pemikiran dan perilaku. Menurut Allport, kepribadian didefinisikan sebagai organisasi dinamis dari sistem psikofisik individu yang menentukan penyesuaian dirinya terhadap lingkungan (Friedman \& Schustack, 2008).Penggolongan tipe kepribadian ekstrovert-introvert didasarkan pada perbedaan respon, kebiasaan, dan sifat-sifat yang ditampilkan oleh individu dalam melakukan hubungan interpersonal, selain itu tipe kepribadian juga menjelaskan posisi kecenderungan individu yang berhubungan dengan reaksi atau tingkah lakunya (Suryabrata, 2002).

Penggolongan tipe kepribadian ekstrovert dan introvertdapat menggambarkan pola komunikasi dan interaksi sosial setiap individu. Pada saat berkomunikasai dan berinteraksi dengan orang lain, individu dengan tipe kepribadian ekstrovert adalah individu dengan karakteristik utama yaitu mudah bergaul, impulsif, tetapi juga sifat gembira, aktif,cakap dan optimis serta sifat-sifat lain yang mengindikasikan penghargaan atas hubungan dengan orang lain, sedangkan individu dengan kepribadian introvert adalah individu yang memiliki karakteristik yang berlawanan dengan tipe kepribadian ekstrovert, yang cenderung pendiam, pasif, tidak mudah bergaul, teliti, pesimis, tenang dan terkontrol (Feist \& Feist, 2010).Secara umum, individu yang tergolong introvert akan lebih berorientasi pada stimulus internal 
dibandingkan dengan individu yang tergolong ekstrovert. Individu yang tergolong introvert akan lebih memperhatikan pikiran, suasana hati dan reaksi-reaksi yang terjadi dalam diri mereka. Hal ini membuat individu yang tergolong introvert cenderung lebih pemalu, memiliki control diri yang kuat, dan memiliki keterpakuan terhadap hal-hal yang terjadi dalam diri mereka serta selalu berusaha untuk mawas diri, tampak pendiam, tidak ramah, lebih suka menyendiri, dan mengalami hambatan pada kualitas tingkah laku yang ditampilkan. Sedangkan individu yang tergolong ekstrovert cenderung tampak lebih bersemangat, mudah bergaul, terkesan impulsif dalam menampilkan tingkah laku. Individu yang tergolong ekstrovert merupakan seseorang yang berani melanggar aturan, memiliki rasa toleransi yang lebih tinggi terhadap rasa sakit, dan lebih mudah terlibat dalam suatu relasi (Burger, 2008).

Penelitian lain menyatakan bahwa pengguna internet yang berjenis kelamin laki-laki dan perempuan, atau yang memiliki kepribadian introvert dan ekstrovert mempunyai kecenderungan memilih layanan yang berbeda dalam penggunaan internet(Raihana, 2009). Selain itu terdapat hubungan yang signifikan anatra tipe kepribadian introvert dengan kecanduan internet pada mahasiswa (Prihati, 2010), padahal dalam kesehariannya, individu dengan tipe kepribadian introvert cenderung pemalu, tertutup dan mengalami kesulitan dalam menjalin hubungan interpersonal dengan orang lain. Menurut Ramdhani (2006) terdapat hubungan antara tipe kepribadian dengan pemilihan media komunikasi khususnya email pada remaja. Penggunaan media jejaring sosial pada dasarnya mampu memenuhi kebutuhan individu dalam berinteraksi dengan orang lain dilingkungan sosialnya. Intensitas komunikasi yang dilakukan individu berkaitan dengan faktor tipe kepribadian yang dimiliki yang dimiliki masing-masing individu, pada tipe kepribadian ekstrovert maupun introvert.Berdasarkan pertimbangan tersebut, peneliti ingin mengetahui apakah terdapat perbedaan intensitas komunikasi melalui jejaring sosial antara tipe kepribadian ekstrovert dan introvert pada remaja.Penelitian ini diharapkan dapat menambah pengetahuan dalam ilmu psikologi, khususnya psikologi komunikasi dan psikologi sosial terkait dengan intensitas komunikasi melalui jejaring sosial pada remaja.Manfaat praktis dari penelitian ini yaitu remaja mampu menggunakan jejaring sosial secara proporsional dengan memperhatikan kelebihan dan kekurangan sesuai dengan tipe kepribadian. Membantu pemerintah dalam mempertimbangkan kebijakan terkait dengan penggunaan media jejaring sosial pada remaja di Indonesia, yang bertujuan untuk mencegah dampak buruk yang ditimbulkan akibat penggunaan media jejaring sosial secara berlebihan, serta sebagai panduan bagi orang tua yang memiliki anak berusia remaja dalam mendidik dan memantau perkembangan anak dalam penggunaan komunikasi melalui jejaring sosial.

\section{METODE}

\section{Variabel dan definisi operasional}

Variabel penelitian adalah segala sesuatu yang menjadi obyek pengamatan penelitian (Suryabrata, 2000).Variabel bebas (independent variabel)merupakan variabel yang mempengaruhi atau yang menjadi sebab perubahan variabel tergantung, dan variabel tergantung(dependent variabel)adalah variabel yang dipengaruhi atau yang menjadi akibat, karena adanya variabel bebas (Sugiyono, 2010). Variabel bebas pada penelitian ini yaitutipe kepribadian ekstrovert dan introvert dan variabel tergantungnya yaitu intensitas komunikasi.

Definisi operasional dari variabel tipe kepribadian ekstrovert adalah seseorang yang memiliki sifat periang dalam berbagai kesempatan, mudah mengambil keputusan, mudah bergaul, senang menerima tantangan, agresif, dan berubahubah, sedangkan individu dengan tipe kepribadian introvert merupakan seseorang yang sulit dalam mengambil keputusan, lebihsuka menyendiri, bersikap hati - hati, pasif dan pendiam.

Definisi operasional dari variabel intensitas komunikasi melalui jejaring sosial adalah komunikasi yang dilakukan oleh pengguna jejaring sosial dengan orang lain secara online. Intensitas komunikasi diukur dengan berdasarkan enam aspek intensitas komunikasi antara lain yaitu frekuensi berkomunikasi, durasi yang digunakan untuk berkomunikasi, perhatian yang diberikan saat berkomunikasi, keteraturan dalam berkomunikasi, tingkat keluasan pesan saat berkomunikasi dan jumlah orang yang diajak berkomunikasi, serta tingkat kedalaman pesan saat berkomunikasi.

\section{Responden}

Populasi merupakan wilayah generalisasi yang terdiri atas obyek yang mempunyai kuantitas dan karakteristik tertentu yang ditetapkan oleh peneliti untuk dipelajari dan kemudian ditarik kesimpulannya, sedangkan sampel merupakan sebagian dari jumlah dan karakteristik yang dimiliki oleh populasi (Boediono \& Koster, 2004). Populasi dalam penelitian ini adalah siswa SMA Negeri di kota Denpasar. Karakteristik sampel pada penelitian ini adalah responden merupakan siswa SMA Negeri di kota Denpasar, berusia 15-18 tahun, bersedia untuk menjadi responden penelitian, dan menggunakan jejaring sosial lebih dari 6 bulan.

Metode pengambilan sampel yang digunakan dalam penelitian ini adalah stratified proporsional randomsampling. Teknik sampling ini dilakukan dengan membagi anggota populasi dalam beberapa sub kelompok atau strata, kemudian sampel dipilih dari masing-masing strata secara acak dengan 
jumlah sampel proporsional pada setiap strata (Danim, 2007). Sebelum pemilihan sampel dilakukan pembagian kelompok strata berdasarkan status sekolah SMA. Dari sekolah SMA yang terpilih tersebut selanjutnya dilakukan pemilihan sampel di masing masing sekolah secara acak untuk mendapat keterwakilan sampel dari masing masing kelas yang ada secara proporsional. Pemilihan sampel pada masing masing kelas menggunakan data list yang sudah ada, dan bila terdapat sampel terpilih berhalangan akan digantikan oleh sampel dengan nomor urut dibawahnya hingga mendapatkan jumlah sampel sesuai yang diharapkan.

\section{Tempat Penelitian}

Responden dalam penelitian ini merupakan siswa SMA Negeri di kota Denpasar, alasan peneliti memilih remaja SMA karena berdasarkan data Kementerian Komunikasi dan Informasi RI tahun 2011 menunjukkanterdapat 64\% pengguna jejaring sosial di Indonesia adalah kelompok remaja (Hariyanti, 2011), sedangkan alasan peneliti memilih kota Denpasar sebagai tempat penelitian dikarenakan Denpasar sebagai ibu kota provinsi Bali, dan di daerah perkotaan akses teknologi dan informasi berkembang dengan pesat.

Berdasarkan hasil proses pengambilan sampel penelitian secara acak terpilih sekolah SMA Negeri 2 Denpasar, SMA Negeri 3 Denpasar dan SMA Negeri 5 Denpasar sebagaitempat penelitian.Dalam menentukan jumlah populasi pada penelitian ini menggunakan rumus jumlah sampel menurut Higgins (dalam Bartlett, Kotrlik, \&Higgins, 2001) sehingga diperoleh hasil jumlah sampel dalam penelitian ini yaitu 240 siswa.

\section{Alat ukur}

Skala pengukuran tipe kepribadianmerupakan adaptasi berdasarkan alat tes EPI(Eysenck Persoality Inventory). EPI adalah alat ukur kepribadian dari Eysenck yang telah baku, EPI digunakan untuk menggolongkan individu ke dalam beberapa tipe kepribadiandengan pilihan jawaban adalah "ya" dan "tidak" (Asriasa, 2010). Dalam alat ukur EPI ini peneliti hanya menggunakan dan menilai aspek yang mengandung penilaian tentang ekstrovert dan introvert yang disesuaikan dengan tujuan penelitian. Kuesioner terdiri dari 23 item pertanyaan.Jawaban responden kemudian disesuaikan dengan kriteria (kunci) jawaban dari tes kepribadian EPIyang telah ada. Apabila jawaban responden sesuai atau sama dengan kriteria jawaban, maka diberi nilai "1". Apabila jawaban responden tidak sama dengan kriteria jawaban maka dinilai "0". Lalu jumlah skor skala dicocokkan dengan norma, norma yang dipakai dalam penggolongan tipe kepribadian ekstrovert dan introvert. Skor ekstrovert mempunyai nilai $\geq 12$, sedangkan introvert mempunyai nilai $\leq$ 11 .
Skala Pengukuran Intensitas Komunikasi terdiri dari pernyataan favorabel dan unfavorabelyang terbagi dalam empat alternatif jawaban, yakni 'sangat tidak setuju', 'tidak setuju', 'setuju', dan 'sangat setuju'. Kedua skala tersebut telah diuji validitas dan reliabilitasnya.

\section{Metode pengumpulan data}

Metode pengumpulan data yang digunakan dalam penelitian ini adalah dengan menggunakan 2 kuesioner, yaitu kuesioner tipe kepribadian dan intensitas komunikasi. Kuesioner tipe kepribadian digunakan untuk mengelompokan responden kedalam tipe kepribadian ekstrovert dan introvert dengan menggunakan kuesioner dengan bentuk pertanyaan yang diadaptasi dari alat tes EPI (Eysenck Personality Inventory) yang diberikan kepada responden untuk pemilihan dan penggolongan responden penelitian, kuesioner untuk mengukur intensitas komunikasi tersedia empat pilihan jawaban, yakni 'sangat tidak setuju', 'tidak setuju', 'setuju', dan 'sangat setuju', dalam kuesioner terdapat arahan mengenai cara menjawab kuesioner, responden diwajibkan untuk memilih salah satu dari alternatif jawaban dan juga mengisi lembaran identitas responden.

\section{Teknik Analisis Data}

Validitas adalah suatu ukuran yang menunjukkan tingkat keabsahan suatu alat ukur.Suatu alat ukur dikatakan valid apabila alat ukur tersebut mampu mengukur yang hendak diukur. Dalam penelitian ini, uji validitas dilakukan dengan pengujian validitas konstruk dan validitas isi, pengujian validitas konstruk dilakukan dengan mencari koefisien korelasi item total (rix) dengan bantuan perangkat lunak SPSS 17.0,suatu item dinyatakan memiliki validitas yang baik dapat diketahui menggunakan tabel product moment correlation untuk mengetahui skor $r$ hitung lalu dibandingkan dengan nilai kritis korelasi pearson atau disebut juga sebagai $r$ tabel. Suatu item dapat dinyatakan valid apabila nilai $r$ hitung $>r$ tabel, namun sebaliknya apabila nilai $r$ tabel $>r$ hitung, maka item tersebut dinyatakan tidak valid (Nurgiyantoro, Gunawan, \& Marzuki, 2004). Pengujian validitas isi menggunakan teknikprofessional judgement, pengujian ini dilakukan dengan menilai item-item skala pengukuran terkait penggunaan tata bahasa yang kurang efektif, kemudian item-item yang kurang efektif tersebut diperbaiki, agar skala tersebut dapat dinyatakan valid dalam hal validitas isi. Suatu alat ukur dapat dikatakan memiliki validitas yang tinggi jika hasilnya sesuai dengan kriteria, dalam arti memiliki kesejajaran antara tes dan kriteria (Arikunto, 2006).

Reliabilitas merujuk pada konsistensi skor yang dicapai oleh orang yang sama ketika dilakukan pengujian ulang dengan alat ukur yang sama pada kesempatan yang berbeda atau dalam kondisi pengujian yang berbeda (Anastasi 
\& Urbina, 2007. Pada penelitian ini uji reliabilitas menggunakan alpha cronbach's dengan bantuan perangkat lunak SPSS 17.0.Suatu alat ukur dinyatakan memiliki reliabilitas yang baik apabila skor alphanya lebih besar dari 0,6 .

Metode analisis data menggunakanindependent sampel t-test, dengan bantuan program SPSS 17.0. Analisis data ini digunakan untuk membandingkan dua kelompok mean dari dua sampel yang berbeda, dan untuk mengetahui perbedaan mean antara dua populasi dengan membandingkan dua mean sample-nya (Sugiyono, 2010).Dalam melakukan analisis data, terdapat dua syarat yang harus dipenuhi, yaitu dilakukannya uji asumsi berupa uji normalitas dan uji homogenitas dengan alat bantu perangkat lunak SPSS 17.0 (Sugiyono,2010 ). Uji normalitas merupakan uji yang dilakukan untuk membuktikan data dari sampel yang dimiliki berasal dari yang populasi berdistribusi normal, pengujian dilakukan dengan kolmogorov-smirnov, data dinyatakan berdistribusi normal jika signifikansi lebih besar dari 0,05 atau 5\% (Arikunto, 2006). Uji homogenitas bertujuan untuk mengetahui apakah kedua sampel mempunyaivarian yang homogen atau tidak, yaitu dengan membandingkan kedua variansnya menggunakan levene's test dengan bantuan perangkat lunak SPSS 17.0. Nilai probalitas lebih besar dari 0,05 maka data berasal dari populasi yang variansnya sama atau homogen (Sugiyono, 2010).

\section{HASIL PENELITIAN}

Uji coba alat ukur dalam penelitian ini dilakukan terhadap responden penelitian, yaitu siswa SMA Negeri di kota Denpasar yang dilaksanakan pada tanggal 1 hingga 5 November 2012. Uji coba penelitian ini dilakukan dengan menyebarkan kuesioner kepada 60 orang responden. Data yang telah diperoleh pada saat melakukan uji coba alat ukur penelitian akan dianalisis untuk mengetahui validitas dan reliabilitasnya. Berdasarkan hasil uji coba item yang terdiri dari 35 item kepada 60 orang subyek, diperoleh koefisien korelasi yang bergerak dari $-0,121$ sampai 0,757. Sesuai dengantaraf signifikan $5 \%$ pada tabel korelasi product moment dengan nilai kritis koefisien korelasi (t tabel) sebesar 0,113, menyatakan bahwa suatu item dapat dinyatakan valid apabila nilai $\mathrm{r}$ hitung $>\mathrm{r}$ tabel, dalam penelitian ini item yang memiliki nilai koefisien korelasi dibawah nilai kritis koefisien korelasi ( $\mathrm{t}$ tabel) digugurkan, sehingga terdapat 7 item gugur dan 28 item valid pada skala intensitas komunikasi, dengan indeks koefisien korelasi yang bergerak dari 0,232-0,742.

Berdasarkan hasil pengujian reliabilitas koefisien alpha $(\alpha)$ pada skala intensitas komunikasipada saat uji coba adalah 0,907, sedangkan hasil koefisien alpha( $\alpha$ ) pada saat penelitian adalah 0,886, hal ini menunjukkan bahwa alat ukur intensitas komunikasi dalam penelitian ini memiliki reliabilitas yang baik. Pada skala tipekepribadian, peneliti menggunakan alat tes EPI (Eysenck Personality Inventory) yang sudah baku. Hasil adaptasi alat ukur itu telah banyak digunakan di Indonesia dengan validitas internal konsistensi yang baik dan tingkat reliabilitas alpha cronbach's berkisar antara 0,89-0,93 untuk ekstrovert-introvert (Syafiq, 2010).Dari hasil uji normalitas awal dengan sampel 240 orang, diketahui bahwa sebaran data pada variabel intensitas komunikasi memiliki nilai signifikansi dengan probabilitas (p) 0.027 atau memiliki probabilitas dibawah 0,05 ( $p<0,05)$, hal tersebut menunjukan bahwa data berdistribusi tidak normal. Berdasarkan penjelasan pada bab III tentang normalitas, adapun cara agar data dapat berdistribusi normal, dapat dilakukan dengan cara menghilangkan outliers dari sampel penelitian dengan alat bantu perangkat lunak SPSS 17.0. Hasil yang diperoleh setelah menghilangkan outliers sebanyak 22orang responden, sehingga sebaran data pada variabel intensitas komunikasi memiliki nilai signifikansi dengan probabilitas (p) 0.084 atau memiliki probabilitas di atas 0,05 ( $p>0,05)$ dengan jumlah sampel terpilih yaitu 218. Dengan mengacu kepada pedoman penentuan normalitas data seperti yang telah dijelaskan sebelumnya, menunjukkan bahwa sebaran data pada variabel intensitas komunikasi dalam penelitian ini adalah bersifat normal.Hasil uji homogenitas telah dilampirkan dalam halaman lampiran. Dari hasil uji homogenitas, diketahui bahwa varianspada setiap kelompok penelitianmemiliki nilai signifikansi dengan probabilitas (p) 0,075 atau memiliki probabilitas di atas 0,05 , haltersebut menunjukkan bahwa varianpada setiap kelompok yang diuji dalam penelitian bersifat homogen.

Setelah kedua syarat untuk melakukan analisis data telah dipenuhi, dilanjutkan dengan menggunakan metode analisis independent samples $\mathrm{t}$ test dengan alat bantu perangkat lunak SPSS 17.0.

\section{Tabel.1}

\section{Hasil uji T}

\begin{tabular}{l}
\hline \multicolumn{2}{c}{ KeteranganNilai } \\
\hline \multicolumn{2}{c}{$\begin{array}{c}\text { Uji Homogenitas } \\
\text { Levene's Test }\end{array}$} \\
Nilai F3.204 \\
Nilai Sig.0.075 \\
Nilai Sig. (2-tailed) 0.000 \\
\hline
\end{tabular}

Berdasarkan hasil analisis data, diperoleh nilai signifikansi $\mathrm{p}$ sebesar 0,000 atau lebih kecil dari 0,05 pada taraf signifikan 0,05 , sehingga dapat disimpulkan bahwa terdapat perbedaan intensitas komunikasi melalui jejaring sosial antara tipe kepribadian ekstrovert dan introvert pada remaja, sehingga hipotesis alternatif $(\mathrm{Ha})$ yang berbunyi “Ada 
perbedaan intensitas komunikasi melalui media jejaring sosial antara tipe kepribadian ekstrovert dan introvert pada remaja" dapat diterima, sedangkan hipotesis nol (Ho) yang berbunyi "Tidak ada perbedaan intensitas komunikasi melalui media jejaring sosial antara tipe kepribadian ekstrovert dan introvert pada remaja" ditolak.

Terkait dengan adanya perbedaan intensitas komunikasi pada kedua kelompok tipe kepribadian, dapat diperjelas dengan adanya pengkategorian kelompok yang memiliki skor intensitas komunikasi dari yang paling tinggi hingga yang paling rendah. Pengkategorian ini dilakukan dengan menggunakan rumus pengkategorian skor dari Azwar (2000).

\begin{tabular}{c|c|c|c|c}
\multicolumn{5}{c}{ Tabel.2 } \\
\multicolumn{5}{c}{ Kategori skor intensitas komunikasi } \\
\hline Nilai & Kategori & Jumlah & Persentas & Kategori \\
\hline skor $\leq 50$ & Sangat Rendah & 11 orang & $5,05 \%$ & Introvert \\
$50<$ skor $\leq 60$ & Rendah & 52 orang & $23,85 \%$ & Introvert \\
$60<$ skor $\leq 70$ & Sedang & 46 orang \&55orang & $41,74 \%$ & Introvert\&Ekstrovert \\
$70<$ skor $\leq 80$ & Tinggi & 45 orang & $20,54 \%$ & Ekstrovert \\
$80<$ skor & Sangat Tinggi & 19 orang & $8,72 \%$ & Ekstrovert \\
\hline
\end{tabular}

Berdasarkan table di atas, maka dapat ditarik kesimpulan bahwa kelompok introvert memiliki skor intensitas komunikasi yangrendah,sedangkan kelompok ekstrovert memiliki skor intensitas komunikasi yang tinggi.

\section{PEMBAHASAN DAN KESIMPULAN}

Manusia sebagai makhluk sosial memiliki suatu kebutuhan atau keinginan untuk menciptakan, menjalin dan menjaga suatu hubungan positif dengan orang lain (Yoseptian, Soewondo, \& Zulkaida, 2011). Dalam menjalin komunikasi perbedaan dapat terlihat pada tipe kepribadian ekstrovert dan introvert, yaitu individu introvert mempunyai kesulitan dalam bersosialisasi dan berinteraksi dengan orang lain disekitarnya, hal ini dikarenakanindividu introvert mencurahkan fokos lebih kedalam diri dari pada diluar dirinya, individu introvert kurang memberikan perhatian lebih terhadap orang-orang yang ada disekitarnya dan lebih merasa nyaman dalam kesendirian serta tergolong orang yang mempunyai sifat pemalu. Hal ini sangat berbeda dengan tipe ekstrovert yang mudah beradaptasi dengan lingkungan yang baru serta tidak mengalami kesulitan untuk dapat menjalin hubungan sosial dengan orang-orang disekitarnya (Suryabrata, 2002).

Menurut Jung (dalam Friedman \& Schustack, 2008)individu dengan tipe kepribadian ekstrovert mempunyai karakteristik lebih ekspresif dalam menyampaikan setiap emosi yang dirasakannya, sehingga hal tersebut membuat orang dengan tipe kepribadian ekstrovert akan lebih mudah untuk mengekspresikan setiap emosi yang dirasakan dengan cara senantiasa menjalin komunikasi secara rutin serta memiliki sifat terbuka, individudengan tipe kepribadian ekstrovert tidak mempersalahkan untuk menyampaikan segala hal, perasaan dan emosi yang dirasakannya melalui berbagai media, salah satunya yaitu jejaring sosial.Pengguna jejaring sosial dengan tipe kepribadian introvert, tidak mudah untuk mengekspresikan dan menyatakan segala hal yang dirasakannya melalui jejaring sosial. Hal ini disebabkan karena tipe kepribadian introvert lebih cenderung mempunyai sifat tertutup, kurang ekspresif dan cenderung berpikir secara mendalam sebelum memutuskan untuk melakukan suatu tindakan(Friedman \& Schustack, 2008). Saat ini tidak dapat dipungkiri bahwa jejaring sosial telah mampu memfasilitasi remaja untuk menjalin relasi dan komunikasi dengan orang lain tanpa dibatasi jarak dan waktu, sehingga pengguna jejaring sosial dapat memenuhi kebutuhan komunikasi mereka, sehingga hasilnya adalah semakin tinggi intensitas komunikasi menggunakan jejaring sosial, semakin memenuhi kebutuhan individu untuk mencari dan menjalin pertemanan dengan orang lain (Yoseptian, Soewondo, \& Zulkaida, 2011).

Hal tersebut menunjukan bahwa intensitas komunikasi individu dengan tipe kepribadian ekstrovert lebih tinggi dibandingkan individu dengan kepribadian introvert. Penjelasan mengenai intensitas komunikasi yang tinggi pada individu dengan kepribadian ekstrovert, dijelaskan Jung (dalam Suryabrata, 2002), Jung menyatakan bahwa pada dasarnya individu dengan tipe kepribadian introvert cenderung lebih menyukai aktivitas yang tidak melibatkan orang-orang disekitarnya dan memberikan perhatian lebih berpusat pada diri sendiri. Hal inilah juga yang membedakan kebutuhan komunikasi antara tipe kepribadian introvert dengan tipe kepribadian ekstrovert, hal ini dikarenakanindividu dengan tipe kepribadian ekstrovert lebih menyukai aktivitas yang melibatkan banyak orang dan lebih berfokus pada dunia diluar dirinya atau dapat diartikan lebih mencurahkan perhatian kepada orang-orang yang ada disekitarnya dibandingkan diri sendiri.

Berdasarkan perbedaan-perbedaan karakteristik yang terdapat pada individu dengan tipe kepribadian ekstrovert dan introvert, sesungguhnya hal inilah yang menyebabkan perbedaan intensitas komunikasi melalui jejaring sosial antara individu dengan tipe kepribadian ekstrovert mempunyai intensitas komunikasi yang lebih tinggi dibandingkan individu dengan tipe kepribadian introvert.

Selanjutnya peneliti mencoba untuk mengkaji secara lebih dalam beberapa hal terkait dengan komunikasi melalui jejaring sosial, antara lain yaitu perbedaan intensitas komunikasi melalui jejaring sosialantara laki-laki dan perempuan, analisis untuk uji perbedaan menggunakan independent sampel t-test. 


\section{Tabel 3}

\section{Hasil uji $T$ analisis tambahan 1}

\begin{tabular}{c}
\hline KeteranganNilai \\
\hline Uji Homogenitas \\
Levene's Test \\
Nilai F.660 \\
Nilai Sig..417 \\
\hline Uji T \\
Nilai Sig. (2-tailed.273 \\
\hline
\end{tabular}

Berdasarkan table di atas,hasil uji homogenitas bahwa varians pada setiap kelompok penelitian memiliki nilai signifikansi dengan probabilitas (p) 0,417 atau memiliki probabilitas di atas 0,05 ( $\mathrm{p}>0,05)$. Dengan mengacu kepada pedoman penentuan homogenitas, nilai probabilitas (p) 0,417 tersebut menunjukkan bahwa varians skor variabel yang diukur pada setiap kelompok yang diuji dalam penelitian ini adalah bersifat homogen, data yang dinyatakan berdistribusi normal jika signifikansi lebih besar dari 0,05 (Arikunto, 2006).

Hasil analisis penelitian memperoleh nilai signifikansi > 0,05, yaitu $\mathrm{p}$ sebesar 0.273, hal tersebut menunjukkan bahwa tidak terdapat perbedaan yang signifikan intensitas komunikasi melalui jejaring sosial berdasarkan jenis kelamin laki-laki dan perempuan. Pada dasarnya komunikasi merupakan bagian dari aktivitas yang tidak dapat terpisahkan dari kehidupan manusia dan hal tersebut tidak melihat dari perbedaan dari jenis kelamin, sehingga dalam melakukan aktivitas komunikasi sehari-hari baik laki-laki maupun perempuan mempunyai kebutuhan yang cenderung sama.Menurut teori perkembangan, remaja sebagai pribadi yang sedang mengalami dinamika dalam proses mencari jati diri menuju dewasa, membutuhkan kehadiran orang lain sebagai bagian penting bagi perkembangan remaja (Christofides, Muise, \& Desmariais, 2009). Pada saat masa remaja seseorang akan merasa lebih senang untuk menghabiskan waktu dengan teman-teman sebaya, serta adanya peningkatan minat terhadap relasi interpersonal. Remaja juga memiliki kebutuhan sosial seperti membangun relasi interpersonal yang lebih besar dibandiingkan dengan individu dewasa (Santrock, 2007). Berdasarkan penjelasan di atas menunjukan bahwa tidak terdapat perbedaan intensitas komunikasi melalui jejaring sosial antara jenis kelamin lakilaki maupun perempuan.

Analisis yang dilakukan untuk mengetahui hubungan antara jumlah jejaring sosial dengan intensitas komunikasi melalui jejaring sosial adalah dengan menggunakan korelasi product moment.Korelasi product moment digunakan untuk mengetahui derajat hubungan dan kontribusi variabel bebas dengan variabel tergantung. Dalam analisis tambahan ini variabel bebas yaitu jumlah jejaring sosial, sedangkan variabel tergantung yaitu intensitas komunikasi. Syarat sebelum melakukan analisis korelasi pearson yaitu data berpola linier dan berdistribusi normal. Linearitas dapat diuji menggunakan compare means dimana nilai plebih kecil dari $0,05(\mathrm{p}<0,05)$ dinyatakan linear (Nurgiyantoro, Gunawan, \& Marzuki, 2004), nilai probabilitas (p) sebesar 0,000 sehingga dikatakan bahwa hubungan jumlah jejaring sosial dengan intensitas komunikasi adalah linear. Uji normalitas menggunakan kolmogorov-smirnov, pada penelitian ini nilai signifikansi dengan probabilitas (p) 0,84 atau mempunyai probalilitas di atas 0,05 ( $\mathrm{p}>0,05)$. Hal ini menunjukkan bahwa sebaran data adalah normal.

Tabel 4

Hasil uji korelasi product moment analisis tambahan 2

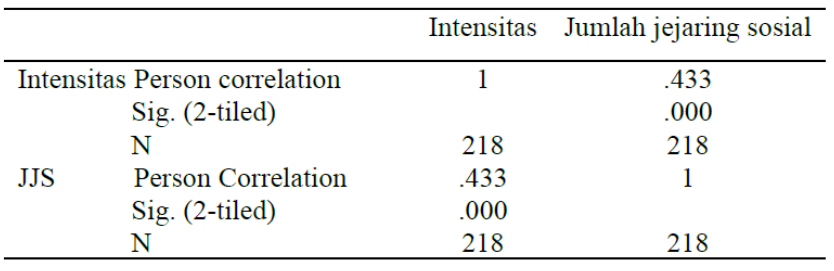

Berdasarkan hasil penelitian dari korelasi variabel jumlah jejaring sosial dan intensitas komunikasi, diperoleh angka probabilitas (p) 0,000, angka tersebut mencerminkan $\mathrm{p}$ $<$ 0,05 yang berarti hipotesis nolnya ditolak dan hipotesis alternatifnya yang menyatakan bahwa terdapat hubungan antara jumlah jejaring sosial dengan intensitas komunikasi diterima.Pada penelitian ini koefisien korelasi (r) sebesar 0.433 menyatakan hubungan antara jumlah jejaring sosial dengan intensitas komunikasi ini tergolong cukup kuat.Koefisien determinasi menunjukkan besarnya sumbangan yang dapat diberikan dari variabel bebas terhadap variabel tergantung.Koefisien determinasi (r2) diperoleh dengan mengkuadratkan nilai $r(0,433)$ sehingga didapatkan hasil $r 2$ sebesar 0,187. Dalam penelitian ini, sumbangan dari variabel jumlah jejaring sosial terhadap variabel intensitas komunikasi sebesar $18,7 \%$ dan $81,3 \%$ lainnya diperoleh dari faktor lainnya.

Jumlah jejaring sosial yang dimiliki seseorang berbanding lurus dengan intensitas komunikasi, angka korelasi yang diperoleh sebesar (+) 0,433, tanda positif (+) menunjukkan bahwa semakin banyak jumlah jejaring sosial maka semakin tinggi intensitas komunikasi, individu yang memiliki jumlah akun jejaring sosial lebih dari 2 merupakan responden dengan tipe kepribadian ekstrovert, sedangkan yang memiliki akun jejaring sosial kurang dari 2 adalah responden introvert. Seseorang yang memiliki akaun lebih dari 2, memiliki motif untuk dapat menjalin hubungan pertemanan dan komunikasi dengan orang lain sebanyak-banyaknya, dibandingkan dengan yang hanya memiliki 1 akun jejaring sosial (Yoseptian, Soewondo, \& Zulkaida, 2011). Komunikasi melalui jejaring sosial juga dipengaruhi oleh faktor lain diantaranya yaitu usia dan daerah tempat tinggal pengguna jejaring sosial,tujuan atau motif menggunakan jejaring sosial 
dan kemudahan cara akses seseorang dalam menggunakan jejaring sosial, serta perbedaan tipe kepribadian pada masingmasing individu (Imran, 2009). Berdasarkan hasil dan pembahasan, maka dapat disimpulkan bahwa perbedaan intensitas komunikasi melalui jejaring sosial antara tipe kepribadian ekstrovert dan tipe kepribadian introvert, tipe kepribadian ekstrovert mempunyai intensitas komunikasi yang lebih tinggi dibandingkan dengan tipe kepribadian introvert.Terdapat perbedaan kecenderungan penggunaan jenis jejaring sosial. Individu dengan tipe kepribadian ekstrovert cenderung menggunakan facebook dan twitter sebanyak $22,9 \%$ dan individu dengan tipe kepribadian introvert sebanyak 36,7\%.Tidak terdapat perbedaan intensitas komunikasi komunikasi melalui jejaring sosial antara laki-laki dan perempuan, serta terdapat hubungan yang signifikan antara jumlah jejaring sosial dengan intensitas komunikasi melalui jejaring sosial.

Saran praktis yang ditujukan bagi sekolah diharapkan hasil penelitian ini dapat dijadikan sebagai masukan dalam membimbing, memantau dan mengarahkan siswanya dalam penggunaan media jejaring secara proporsional dengan memperhatikan kelebihan dan kekurangan dari jenis-jenis jejaring sosial. Pihak sekolah dapat menyediakan ruangan bebas wifi yang dapat dimanfaatkan oleh siswa dalam mengakses jejaring sosial, namun tetap diawasi penggunaannya, melalui BK (Bimbingan Konseling) memberikan sosialisasi terkait dampak penggunaan media jejaring sosial, sehingga pengguna dapat menggunakan jejaring sosial sebagai media interaksi interpersonal dengan cara yang bijaksana sehingga dapat memberikan hal positif bagi perkembangan pribadi remaja.

Saran bagi penelitian selanjutnya yaitu diharapkan dapat menggali fenomena secara lebih mendalam dalam penggunaan media jejaring sosial dengan melakukansurvey atau wawancara awal yang dapat dijadikan sebagai sumber untuk landasan teori. Teknik pengumpulan data tidak hanya menggunakan alat ukur atau kuesioner berdasarkan variabel yang ingin diteliti saja, namun dapat juga ditambah dengan menggunakan metode wawancara, sehingga diharapkan dengan dilakukan wawancara dapat menggali serta memperoleh informasi dan data yang lebih mendalam. Peneliti selanjutnya agar menggunakan alat ukur yang telah diadaptasi, tervalidasi dengan baik serta realibel terkait dengan tipe kepribadian ekstrovert dan introvert, sehingga dapat mengurangi terjadinya kesalahan pada alat ukur dan lebih efisien dalam penggunaannya, namun juga disesuaikandengan keadaan budaya tempat pelaksanaan penelitian

\section{DAFTAR PUSTAKA}

Aditya, D. (2009). Jenis - jenis media jejaring sosial. Jakarta.
Amiel, T., \& Sargent, S. L. (2004). Computer in human behavior 20. Individual differences in internet usage motives, 771-726.

Anastasi, A., \& Urbina, S. (2007). Tes psikologi. Jakarta: PT Indeks.

Arfika. (2012, September 24). Jejaring Sosial Menggantikan Komunikasi Face to Face. TV Kompas.

Arikunto, S. (2006). Prosedur Penelitian (suatu pendekatan praktik). jakarta: Rineka.

Asriasa, A. (2010). hubungan tipe Kepribadian Dengan Minat Aroma Parfum Pada Santri Putri Ma'had Sunan Ampel Al-Ali Universitas Islam Negeri Maulana Malik Ibrahim Malang.

Bartlett, J. E., Kotrlik, j. W., \& Higgins, C. C. (2001). Informational technology, learning n performance journal. organizational research: determining appropriate sample zize in survey research, vol 19 no 1.

Boediono, \& Koster, W. (2004). Statistika dan Probabilitas. Bandung: PT Remaja Rosdakarya.

Burger, J. M. (2008). Personality seventh edition. Canada: Nelson Education.ltd.

Cangara, H. (2011). Pengantar ilmu komunikasi . Jakarta: PT Raja Grafindo Persada.

Christofides, E., Muise, A., \& Desmariais, S. (2009). Information disclosure and control on facebook. journal of cyberpsychology \& personality and social psychology, 314345.

Coget, J. F., Yamauchi, Y., \& Suman, M. (2002). IT\&Society. The Internet, Social Networks And Loneliness, 180-201.

Devito, J. A. (1997). Komunikasi antar manusia kuliah dasar edisi kelima. Jakarta: Professional Books.

Feist, J., \& Feist, G. J. (2010). Teori kepribadian. Jakarta: Salemba humanika.

Friedman, H. S., \& Schustack, M. W. (2008). Kepribadian teori klasik dan riset modern. Jakarta: Erlangga.

Hall, C. S. (1985). Introduction to theories of personality. Canada: Jhon wiley\& Sons.Inc.

Hariyanti, D. (2011, Juli 14). Remaja, 64 Persen Pengguna Jejaring Sosial . Jurnas.com.

Imran, H. A. (2009). Aktifitas komunikasi dan media jejaring sosial.

Juditha, C. (2011). Hubungan penggunaan situs jejaring sosial facebook terhadap perilaku remaja di kota Makasar, 1.

Luwu, T. (2012, Februari). Kompas.com. Retrieved September 5, 2012, from Siswi SMK Diculik Teman Facebook: http://regional.kompas.com/read/2013/01/30/16373730/Sis wi.SMK.Diculik.Teman.Facebook

Nurgiyantoro, B., Gunawan, \& Marzuki. (2004). Statistik terapan untuk penelitian ilmu-ilmu sosial. Yogyakarta: Gadjah mada university press

Papalia, D. E., Olds, S. W., \& Feldman, R. D. (2007). Human Development. New york: McGraw Hill.

Peni, W. (2012, Maret). Vivanews. Retrieved September 5, 2012, from Koalisi Rakyat Bali Tanggapi Facebook Ibnu: http://nasional.news.viva.co.id/news/read/137311koalisi_rakyat_bali_tanggapi_facebook_ibnu

Pervin, L. A., Cervone, D., \& Jhon, O. P. (2010). Psikologi kepribadian teori dan penelitian. Jakarta: Kencana prenada media group.

Prihati, M., Zulkaida, A., \& Harsanti, I. (2010). Kontribusi kepribadian introvert terhadap kecanduan internet pada mahasiswa. 
Raihana, P. a. (2009). Perbedaan kecenderungan kecanduan internet ditinjau dari tipe kepribadian introvert-ekstrovert dan jenis kelamin.

Ramdhani, N. (2006). Meta-analysis Towards the Relationship between Extraversion, Neuroticism, and Openness to Experience with Email Usage.

Riduwan, \& Sunarto. (2010). pengantar statistika untuk penelitian pendidikan, sosial, komunikasi, ekonomi, dan bisnis. Bandung: Alfabeta Bandung.

Santrock, J. W. (2007). Remaja edisi kesebelas. Jakarta: Erlangga.

Sarwono, S. W. (2012). Pengantar Psikologi Umum. Jakarta: PT Raja Grafindo Persada.

Sarwono, S. W. (2012). Psikologi Remaja. Jakarta: PT Raja Grafindo.

Sugiyono. (2001). Statistika untuk Penelitian. Bandung: Alfabeta.

Sulaeman, B. (2010). Perbedaan intensitas komunikasi melalui blackberry messenger berdasarkan tipe kepribadian ekstrover dan introvert pada mahasiswa Universitas Bina Nusantara.

Sunggiardi, M. S. (2012, Maret 14). World Economic Forum. Perkembangan Internet 2012.

Suryabrata, S. (2000). Metodologi penelitian. Jakarta: PT Raja Grafindo Persada.

Suryabrata, S. (2002). Psikologi kepribadian. Jakarta: PT Rajawali Pers.

Syafiq, M. (2010). Hubungan kepribadian dengan penyesuaian diri siswa.

Tubbs, S. L., \& Moss, S. (2005). Human Communication . Bandung: PT Remaja Rosdakarya.

Yoseptian, L., Soewondo, S., \& Zulkaida, A. (2011). Kebutuhan afiliasi pada mahasiswa pengguna facebook. 